\title{
Plasma Induced Physicochemical Changes and Reactive Dyeing of Wool Fabrics
}

\author{
J. Udakhe, S. Honade, and N. Shrivastava \\ Textile Chemical \& Colour Department, Wool Research Association, Thane 400 607, India \\ Correspondence should be addressed to J. Udakhe; jayantudakhe@gmail.com
}

Received 30 June 2015; Accepted 11 October 2015

Academic Editor: Rodrigo Martins

Copyright ( $2015 \mathrm{~J}$. Udakhe et al. This is an open access article distributed under the Creative Commons Attribution License, which permits unrestricted use, distribution, and reproduction in any medium, provided the original work is properly cited.

\begin{abstract}
This study focuses on the effect of dielectric barrier discharge (DBD) plasma treatment on physical and chemical properties of wool fabric and its relation to exhaustion of Drimalan Navy Blue FBI reactive dye. AFM analysis of plasma treated wool fabric has shown partial removal of epicuticle and thus reduced scale height. FD spectroscopy has shown improvement in hydrophilicity by many folds after plasma treatment. ATR graphs depict the removal of hydrophobic layer of 18-MEA and introduction of hydrophilic groups like cysteic acid after plasma treatment. Alkali solubility of wool fabric increases with increasing plasma treatment time. Wetting time for plasma treated fabric reduces drastically when compared to untreated wool fabric. It is found that plasma treated fabric takes much lesser time to reach maximum dye exhaustion than untreated fabric. Substantivity of the dye increases significantly after plasma treatment. Colour fastness properties improve with increase in plasma treatment time. Chemical oxygen demand (COD) of spent dyebath liquor is found to reduce with increase in plasma treatment time. Biological oxygen demand (BOD) is found to be higher for plasma treated samples, while ratio of COD/BOD has reduced with increase in the plasma treatment time.
\end{abstract}

\section{Introduction}

The wool fibre exhibits a typical core-shell structure consisting of an inner protein core, the cortex, which is covered by overlapping cuticle cells with scale edges pointing in the direction of the fibre [1]. The keratinous or cysteine disulphide cross-linked proteins present in the cuticle are responsible for most of physical properties of wool and thus the reactivity of the cysteine disulphide residue is of paramount importance [2]. The outer surface of the cuticle cells contains a covalently bound fatty acid, the chiral 18methyleicosanoic acid (18-MEA), very probably bound via a thioester linkage which imparts hydrophobic nature to the fibre surface [3]. The high cross-linking density and hydrophobic nature of the outermost fibre surface act as a diffusion barrier and protect the native wool fibre from environmental influences and wool finishing processes $[1,4]$.

Therefore, in wool finishing processes, such as printing, dyeing, or shrink-proofing, surface modification plays an important role. To date, the required surface modification is mainly accomplished by wet chemical processes using special auxiliaries or chemical surface oxidation, for example, the chlorination processes. Since concern for the environment and introduction of strict ecological legislation has caused environmental pressure on industry, the application of low temperature plasmas to wool has recently become of increasing interest, particularly with regard to an improvement of dye uptake and to replace the chlorination stages in commercial shrink proofing and printing $[1,5]$.

New techniques to increase the dye exhaustion leading to reduction in effluent load are being investigated worldwide. Many researchers are focusing on the use of environmentally friendly techniques like low temperature plasmas as pretreatment for enhancing the wet processes in wool $[6,7]$. Radetic et al. [8] have reported the better exhaustion of acid and direct dyes on plasma treated hemp fabric. Kan $[9,10]$ has studied the dyeing behavior of acid, metal complex, and reactive dyes on glow discharge plasma treated wool fabrics. Wakida et al. [11] have shown that the rate of dyeing of acid and basic dyes on wool increases after plasma treatment. Similar other studies [12-15] on natural dyes on plasma treated wool are also reported for better exhaustion properties, color strength, and fastness properties. Atav and Yurdakul [16] have 
reported that plasma treated mohair fibres can be dyed at lower temperatures $\left(90^{\circ} \mathrm{C}\right)$ and for shorter times $(1 \mathrm{~h}$ instead of $1.5 \mathrm{~h}$ ) with reactive dye without causing any decrease in colour yield. In our previous work [17] we have studied the correlation between physicochemical changes and dyeing behavior of wool fabric with acid dyes after dielectric barrier discharge (DBD) plasma treatment.

In the light of increasing environmental concerns with heavy metals, it is desirable to use reactive dyes to match deep shades of black and navy blue in order to offer the dyer a real alternative to chrome dyes. In this context, dye manufacturers have increased their efforts to offer wool dyers with ranges of attractively priced reactive dyes; examples include Lanasol CE dyes from Ciba, Realan dyes from DyStar, and Drimalan dyes from Clariant [2]. The effects of DBD plasma treatment time and reactive dyeing of wool fabrics are rarely reported in research papers. Hence this paper focuses on finding a correlation between plasma treatment times, dye exhaustion, dyeing time, and colour fastness properties along with effluent load in the exhaust bath. Many studies have reported that the chemical changes induced by plasma treatment are found to lessen over a period of time and the substrate regains its original chemical state. Hence to take the full advantage of the physicochemical changes which occurred during plasma treatment, the plasma treated wool fabrics were dyed within $12 \mathrm{hrs}$ after carrying out plasma treatment on wool fabrics.

\section{Materials and Methods}

2.1. Materials. Wool fabric was procured from Bhutti weaver's cooperative society Ltd., Himachal Pradesh, India. Merino wool fabric having $22.5 \mu \mathrm{m}$ wool, warp, and weft count of $2 / 47 \mathrm{Nm}, 2 / 2$ twill weave, and 52/40 EPI/PPI was used in the study. Lissapol-N (nonionic detergent) was procured from ICI India Ltd., Mumbai, India, and used for scouring of wool fabric. Drimalan Navy Blue FBI reactive dye was obtained from Clariant Mumbai, India. All other chemicals used were LR grade.

2.2. Fabric Scouring. To remove the lubricants and antistatic, fabric was scoured using $0.5 \%$ o.w.f. Lissapol-N at $60^{\circ} \mathrm{C}$ for $30 \mathrm{~min}$ at $\mathrm{M}: \mathrm{L}$ of $1: 30$, hydroextracted, dried at room temperature, and further used for plasma treatment.

\subsection{Plasma Treatment. A dielectric barrier discharge (DBD)} plasma reactor was employed for plasma treatment of wool fabrics. Plasma treatment was carried out at atmospheric pressure using $2 \mathrm{~mm}$ electrode spacing, $5 \mathrm{kV}$ voltage, and 0.8 A current across the electrodes. Air was used as the nonpolymerizing gas for plasma treatment. In our previous work [18], we found that the efficiency of plasma treatment in terms of surface etching is inversely proportional to the electrode spacing, provided that all other parameters like voltage and current remain the same. Hence for all the experiments, electrode spacing was kept at minimum possible level, that is, $2 \mathrm{~mm}$, while plasma treatment was given
TABLE 1: Plasma treatment parameters.

\begin{tabular}{lcccc}
\hline $\begin{array}{l}\text { Sample } \\
\text { code }\end{array}$ & $\begin{array}{c}\text { Treatment time } \\
(\mathrm{min})\end{array}$ & $\begin{array}{c}\text { Electrode spacing } \\
(\mathrm{mm})\end{array}$ & $\begin{array}{c}\text { Voltage } \\
(\mathrm{kV})\end{array}$ & $\begin{array}{c}\text { Current } \\
(\mathrm{A})\end{array}$ \\
\hline $\mathrm{UT}$ & 0 & - & - & - \\
$1 \mathrm{mPT}$ & 1 & 2 & 5 & 0.8 \\
$2.5 \mathrm{mPT}$ & 2.5 & 2 & 5 & 0.8 \\
$5 \mathrm{mPT}$ & 5 & 2 & 5 & 0.8 \\
$10 \mathrm{mPT}$ & 10 & 2 & 5 & 0.8 \\
$15 \mathrm{mPT}$ & 15 & 2 & 5 & 0.8 \\
\hline
\end{tabular}

to wool fabric samples. The different parameters used for plasma treatment are given in Table 1.

2.4. Dying of Wool Fabrics. Wool fabrics were dyed using Drimalan Navy Blue FBI reactive dye, 2\% o.w.f. in an infracolour dyeing machine. The dyeing material to liquor ratio $(\mathrm{M}: \mathrm{L})$ was $1: 20$, and the dyebath $\mathrm{pH}$ was maintained at 5.5. Wool fabric samples ( $5 \mathrm{gm}$ each) were immersed into the dyeing solution at room temperature $\left(30^{\circ} \mathrm{C}\right)$ and heated at the rate of $2^{\circ} \mathrm{C} / \mathrm{min}$ to achieve final dyeing temperature of $98^{\circ} \mathrm{C}$. Total dyeing time was $180 \mathrm{~m}$ followed by fixation of dye. The fixation of dye was carried out at $85^{\circ} \mathrm{C}$ for $20 \mathrm{~min}$ using ammonia at $\mathrm{pH} 8.5$ and $\mathrm{M}: \mathrm{L}$ of $1: 20$. Subsequently the samples were washed thoroughly and dried at room temperature.

\subsection{Testing and Characterization Methods}

2.5.1. Atomic Force Microscopy. Effect of plasma treatment on surface morphology and scale heights was studied on Nanonics MultiView 1000 scanning probe microscope. The measurements were performed with AFM glass cantilevered probe, tip radius $<10 \mathrm{~nm}$ (Nanonics Imaging). Force distance (FD) measurements were performed to measure adhesion force between fibre surface and AFM tip; the measurements were done at different locations along the fibers. Adhesion force between AFM tip and wool fibre surface was studied, as it characterizes the hydrophilic properties of the surface. Higher adhesion forces indicate hydrophilic and lesser force corresponds to hydrophobic nature of the surface. Adhesion force (in $\mathrm{nN}$ ) was determined from jump of contact in region of retract curve. Line scans of the topographic images were also studied for comparison of scale heights of untreated and $2.5 \mathrm{~min}$ and $15 \mathrm{~min}$ plasma treated samples.

2.5.2. FTIR-ATR Spectroscopy. Attenuated total reflectance (ATR) mode of FTIR was used for studying the probable change in the structural groups on the surface of plasma treated fabrics. FTIR-8400S Shimadzu model was used and scanning was performed from $4000 \mathrm{~cm}^{-1}$ to $700 \mathrm{~cm}^{-1}$.

2.5.3. Alkali Solubility. Alkali solubility of wool is an indication of the extent of damage to the epicuticle layer. The epicuticle layer is major hindrance to penetration of chemical species and thus protects native wool fibre from damage. 
To quantify the damage to the epicuticle, alkali solubility of untreated and plasma treated fabrics were studied using BS 3568:1962 standard test method. The values were calculated as a percentage of the original mass, according to the equation given in the following:

$$
\text { Alkali solubility }(\%)=\frac{M_{1}-M_{2}}{M_{1}} \times 100 \text {, }
$$

where $M_{1}$ is the mass of oven dry sample before sodium hydroxide treatment and $M_{2}$ is the mass of oven dry sample after sodium hydroxide treatment [16].

2.5.4. Wetting Time. The moisture absorption of untreated and plasma treated wool fabrics was measured using standard test method BS 4554:1970. At least two specimens were tested and fifteen readings were taken on each specimen; the average of thirty readings was quoted as wetting time. Wetting time is defined as the time (in seconds) for a drop of water to get absorbed/get down into the fabric sample.

2.5.5. Dyeing Kinetics and Colour Strength. In order to study the dyeing kinetics of Drimalan Navy Blue FBI reactive dye on wool fabric, dyeing samples were taken out at every 15 min to study the exhaustion at particular time interval. The absorbance values of spent dye bath liquors were analyzed using a UV-VIS Spectrophotometer GBC UV/VIS 918 in a $10 \mathrm{~mm}$ glass absorption cell (Optiglass Ltd., UK). All measurements of dye solution were conducted at room temperature. Absorbance of dye solution was measured at wavelength of maximum absorbance $\left(\lambda_{\max }\right) 591.4 \mathrm{~nm}$. Dye exhaustion \% was estimated using the following equation:

$$
\% \text { Exhaustion }=\frac{A_{0}-A_{s}}{A_{0}} \times 100 \text {, }
$$

where $A_{0}$ and $A_{s}$ are the absorbance of dye in the dyebath initially and after dyeing, respectively. Based on the exhaustion data, substantivity $(K)$ of the dye for untreated and plasma treated fabrics was calculated. Substantivity represents the extent to which dye prefers the fibre to the dyebath in the particular dyebath condition and was calculated using the following equation:

$$
K=\frac{\% \mathrm{EXL}}{100-\% E}
$$

where $K$ is the substantivity, $\% E$ is percentage of dye exhaustion, and $L$ is liquor ratio. The $K$ value reflects how efficiently the dye has been transferred from the bath to the fibre. The greater the value of $K$ is, the better the dye is retained in the fibre.

Depth of colour on the dyed wool fabrics was studied using X-rite i-7 spectrophotometer. Colour strength $(K / S)$ of the dyed samples was measured at $\lambda_{\max }$ of $605 \mathrm{~nm}$ and measurements were done using $17 \mathrm{~mm}$ aperture. Total sixteen readings were taken for each sample and the average $K / S$ value was calculated.
2.5.6. Colour Fastness Properties. Colour fastness to daylight was tested using BS EN ISO 105-B01:1999 test method. Specimens of dyed wool fabrics were exposed to daylight under prescribed conditions, including protection from rain, along with eight dyed blue wool references. The colour fastness was assessed by comparing the change in colour of the test specimen with that of the references used. Colour fastness to artificial light was also tested using ISO 105B02:1990 test method using Atlas Xenotest alpha light fastness tester. Colour fastness to washing was studied using EN ISO 105-C10:2007 (2B) test method using Paramount make Digiwash-INX washing fastness tester. Dyed wool fabrics were sandwiched between wool and cotton fabrics and washed. Staining against cotton, wool, and change in shade were measured. Colour fastness to rubbing was tested using EN ISO 105-X12:2002 test method using Paramount make crockmeter-I rubbing fastness tester. Rubbing fastness was tested against dry and wet cotton fabric and analyzed with SDC grey scale.

2.5.7. Chemical and Biological Oxygen Demand. The chemical oxygen demand (COD) of the spent bath liquor was tested using standard test method ISO 15705:2002, also called sealed tube method. The COD was determined using Lovibond COD Vario MD 200 instrument. The samples were first digested (oxidized) at $150^{\circ} \mathrm{C}$ for $2 \mathrm{hrs}$ and then the COD was measured using photometric method. Biological oxygen demand (BOD) of the spent bath liquor was determined using standard test method for water and wastewater analysis 5210-B and calculated using the following equation:

$$
\mathrm{BOD}=\frac{\left[\left(D_{0}-D_{5}\right)-\left(B_{0}-B_{5}\right)\right] \times 100}{p},
$$

where $D_{0}$ and $D_{5}$ are the dissolved oxygen levels $(\mathrm{mg} / \mathrm{L})$ in effluent sample on day 1 and day 5 , respectively, and $B_{0}$ and $B_{5}$ are the dissolved oxygen levels $(\mathrm{mg} / \mathrm{L})$ in bacteria seeded clean water sample on day 1 and day 5 , whereas $p$ is the $\%$ of added effluent.

\section{Results and Discussion}

The atomic force microscopy (AFM) image (Figure 1(a)) shows that the untreated wool fibre surface was smooth whereas plasma treated wool fibre (Figure 1(b)) shows surface etching which resulted in a rougher and larger surface area. When the excited and energetic plasma species (ions, radicals, electrons, and metastables) are bombarded on the textile or polymer surfaces, they initiate various reactions like chain scission resulting in surface etching, activation, and surface cleaning [19]. The untreated wool fibre sample was found to be smooth and plasma treated samples showed formation of small pores on the fibre surface. Plasma treatment for longer time (e.g., $15 \mathrm{~min}$ ) rendered the surface with more pores; this active surface provides very less or no resistance for the penetration of dyes and chemicals. The results of adhesion forces (Table 2) show that the wool fibers plasma treated for $15 \mathrm{~min}$ have a stronger adhesion force relative to $2.5 \mathrm{~min}$ plasma treated and untreated fibers. Plasma treatment for 


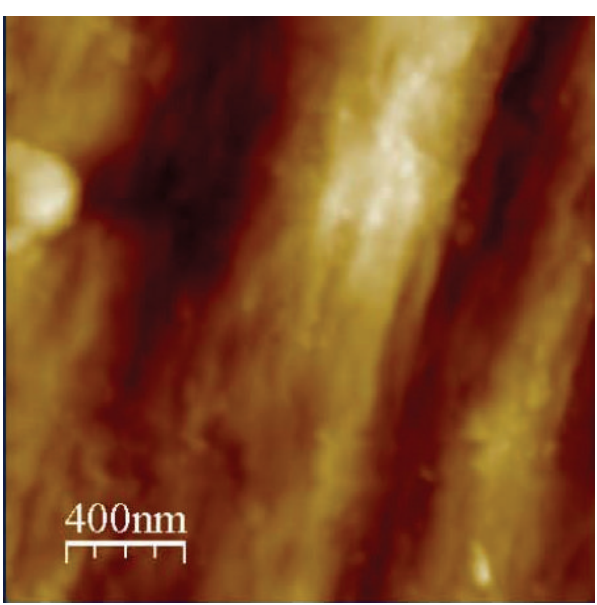

(a)

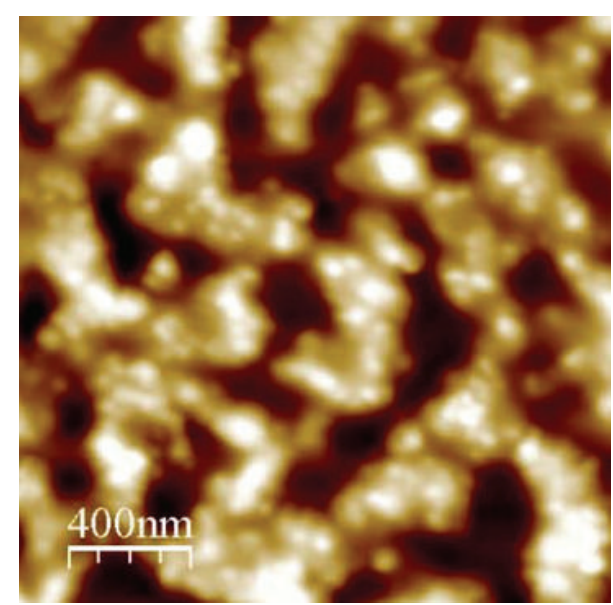

(b)

Figure 1: AFM images of (a) untreated and (b) 15 min plasma treated wool fibres ( $2 \mu \mathrm{m}^{2}$ scanned area).

TABLE 2: Surface characteristics and hydrophilicity.

\begin{tabular}{lcccc}
\hline $\begin{array}{l}\text { Sample } \\
\text { code }\end{array}$ & $\begin{array}{c}\text { Adhesion } \\
\text { force } \\
(\mathrm{nN})\end{array}$ & $\begin{array}{c}\text { Scale } \\
\text { heights } \\
(\mu \mathrm{m})\end{array}$ & $\begin{array}{c}\text { Alkali } \\
\text { solubility } \\
(\%)\end{array}$ & $\begin{array}{c}\text { Absorbency } \\
\text { time } \\
(\mathrm{S})\end{array}$ \\
\hline $\mathrm{UT}$ & 1 & 1.7 & 15.00 & Nonwettable \\
$1 \mathrm{mPT}$ & - & - & 15.23 & 60 \\
$2.5 \mathrm{mPT}$ & 3 & 0.6 & 16.01 & 37 \\
$5 \mathrm{mPT}$ & - & - & 17.36 & 19 \\
$10 \mathrm{mPT}$ & - & - & 17.88 & 7 \\
$15 \mathrm{mPT}$ & 6 & 0.34 & 18.35 & 1 \\
\hline
\end{tabular}

15 min has increased the hydrophilicity of untreated samples by around six times. Line scan was performed on the wool fibre samples (Table 2) for measurement of scale heights before and after plasma treatment. It was found that the height of scale on untreated wool fibre was around $1.7 \mu \mathrm{m}$, while it reduced to $0.6 \mu \mathrm{m}$ for $2.5 \mathrm{~min}$ plasma treated sample and the height got further reduced to $0.34 \mu \mathrm{m}$ for $15 \mathrm{~min}$ plasma treated samples. This suggests that plasma treatment removes the epicuticle layer which is known for having high density of cysteine linkages, being hydrophobic in nature, and being the main barrier for absorption of dyes and other chemicals.

Attenuated total reflectance (ATR) spectra (Figure 2) of the untreated and 15 min plasma treated wool fabrics are illustrated. Two sharp peaks in the range of 2935-2915/2865$2845 \mathrm{~cm}^{-1}$ for untreated wool fabric samples correspond to Methylene $-\mathrm{CH}_{2}$ - asymmetric/symmetric stretch and similarly in the range of $1485-1445 \mathrm{~cm}^{-1}$ they correspond to Methylene $-\mathrm{CH}_{2}-$ bend [20]. Intensity of these peaks in untreated sample is high, while after plasma treatment the intensity of all these peaks (Methylene $-\mathrm{CH}_{2}-$ stretch and bend) has reduced, indicating the removal of 18-MEA acid covalently bonded to epicuticle. The peak at $1745 \mathrm{~cm}^{-1}$ for

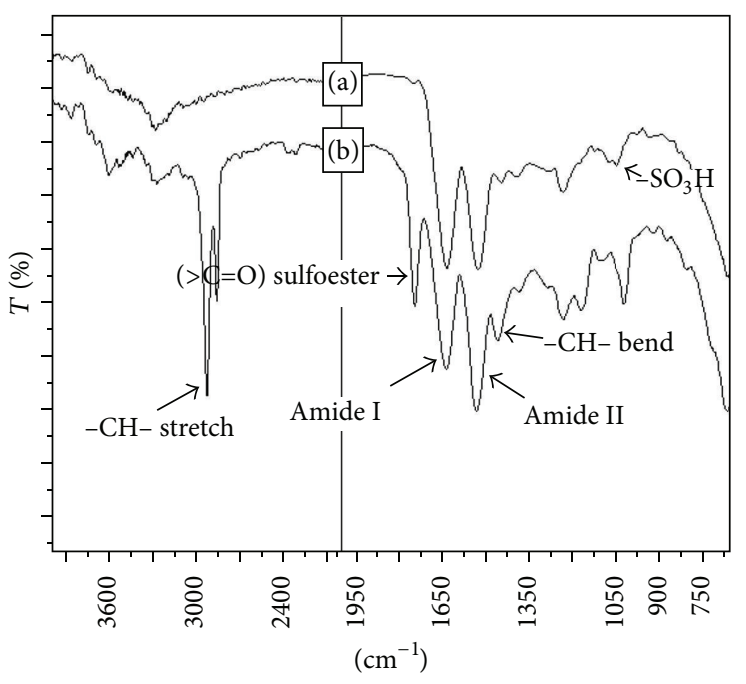

FIGURE 2: FTIR-ATR plots of (a) 15 min plasma treated and (b) untreated wool fabrics.

untreated wool fabric corresponds to covalent bond of 18MEA acid to epicuticle through the $(>\mathrm{C}=\mathrm{O})$ sulfoester. After plasma treatment, this bond breaks and it can be seen from ATR of plasma treatments that peak at $1745 \mathrm{~cm}^{-1}$ disappears. The two spectra reveal that the bands near $1600 \mathrm{~cm}^{-1}$ assigned to amide I and amide II vibrations are shifted. They reveal a combination of amide $\mathrm{C}=\mathrm{O}$ and $\mathrm{N}-\mathrm{H}$ modes. The frequency is sensitive to protein conformation, that is, alpha helix, random, beta-sheet, and so forth. The intensity is proportional to the concentration of amide linkage, that is, $-\mathrm{C}(=\mathrm{O})-\mathrm{N}(-$ $\mathrm{H})-$. Yet in this case, it is suspected that the differences are ascribed to the differences in the water content of fibers. There is an $\mathrm{H}-\mathrm{O}-\mathrm{H}$ bending mode at ca. $1640 \mathrm{~cm}^{-1}$. This is supposed to push up the intensity of amide I peak after plasma treatment [5]. After plasma treatment, an additional peak appears at $1047 \mathrm{~cm}^{-1}$ which corresponds to cysteic acid $\left(-\mathrm{SO}_{3} \mathrm{H}\right)$; this indicates the decrease of $-\mathrm{S}-\mathrm{S}-$ from wool fibre 


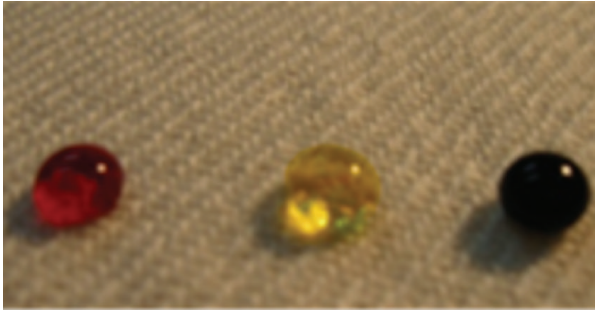

(a)

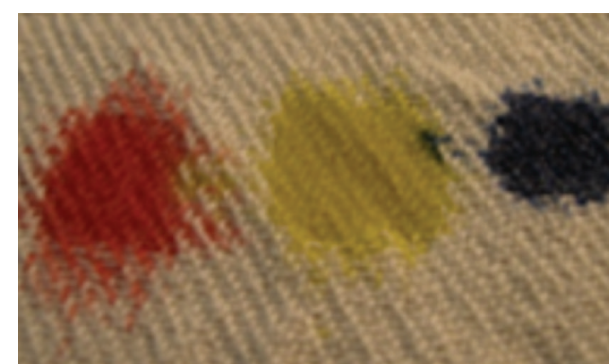

(b)

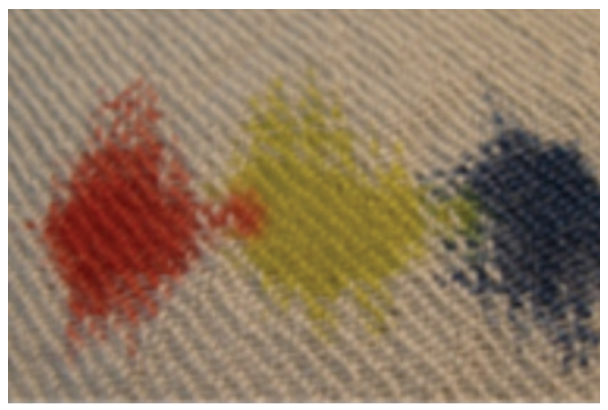

(c)

FIGURE 3: Photographs of dye drops on (a) untreated, (b) 2.5 min plasma treated, and (c) 15 min plasma treated wool fabrics.

and subsequently this group gets converted to the $-\mathrm{S}-\mathrm{O}$ and $-\mathrm{S}=\mathrm{O}$ groups. This indicates the oxidation of $-\mathrm{S}-\mathrm{S}-$ in the surface of wool after plasma treatment [20-22].

The alkali solubility (Table 2) of the plasma treated fabric was tested and compared with the untreated sample. The alkali solubility values (as reported in literature) for undamaged wool fibres are between 9 and $15 \%$. The alkali solubility of plasma treated wool fibres was found to increase compared to untreated fibres. This increase in solubility of the plasma treated fibres is due to removal of 18-MEA from the epicuticle and generation of more hydrophilic sites on the fibre surface. Also it is found that plasma treatment create pores on the fibre surface, as observed in AFM images, creating a pathway for the penetration of caustic species into the fibre during the alkali solubility test.

The increased hydrophilicity of treated fabric is shown in Table 2 as a decrease in water absorbency time compared to the untreated fabric. Water absorbency time had decreased from more than 60 seconds (nonwettable) for untreated fabric to $1 \mathrm{~s}$ after 15 min plasma treatment. This sharp decrease in water absorbency time after plasma treatment can be explained by an increase in surface hydrophilicity due to formation of microcracks and removal of scales on wool fibre surface. With respect to the ATR spectroscopy of plasma treated fabric, it was found that layer of 18-MEA acid was removed and hydrophilic groups like cysteic acid $\left(-\mathrm{SO}_{3} \mathrm{H}\right)$ were generated on the surface. This also plays an important role in increasing the moisture adsorption [21].

Untreated sample (Figure 3(a)) do not absorb dye drops at all; it was observed that the dye drops were not absorbed even after $30 \mathrm{~min}$ and could be rolled off easily from the fabric surface without wetting and staining. In plasma treated samples for $2.5 \mathrm{~min}$ and $15 \mathrm{~min}$ treatment time (Figures 3(b)

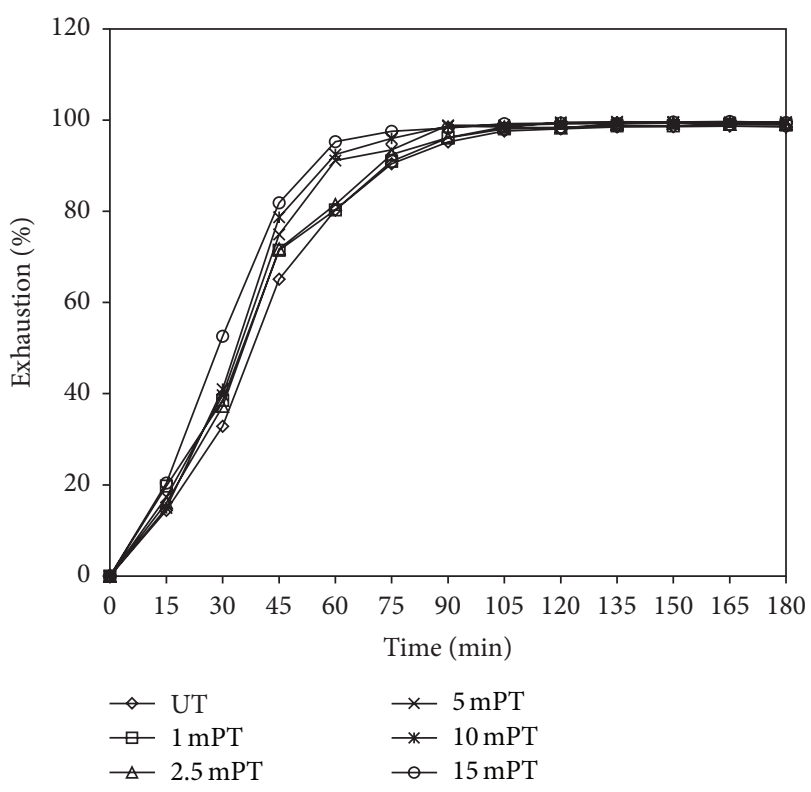

FIGURE 4: Reactive dye exhaustion curves on wool fabrics.

and 3(c)), respectively, the dye drops got spread and absorbed over the surface, due to increased hydrophilicity as compared to untreated sample.

The dyeing kinetics of Drimalan Navy Blue FBI reactive dye on fabric samples (Figure 4) shows that initial exhaustion or rush of dye towards fabric increases with increase in the plasma treatment time. Untreated wool fabric sample took 120 min dyeing time to reach maximum exhaustion (around 98\%) while the dyeing time to reach similar level 
TABle 3: Dye uptake and colour strength.

\begin{tabular}{lccccc}
\hline Sample code & $\begin{array}{c}\text { Dyeing time } \\
(\mathrm{min})\end{array}$ & \% $E$ at $E_{\max }$ & Liquor ratio & \multicolumn{2}{c}{$\begin{array}{c}\text { Substantivity } \\
(K)\end{array}$} \\
\hline $\mathrm{UT}$ & 120 & 98.14 & 20 & 1054.07 & \multicolumn{2}{c}{ Colour strength } \\
$1 \mathrm{mPT}$ & 105 & 99.29 & 20 & 2814.59 & 28.26 \\
$2.5 \mathrm{mPT}$ & 105 & 99.38 & 20 & 3230.00 & 28.68 \\
$5 \mathrm{mPT}$ & 90 & 99.61 & 20 & 5074.59 & 28.91 \\
$10 \mathrm{mPT}$ & 90 & 99.64 & 20 & 5606.87 & 29.84 \\
$15 \mathrm{mPT}$ & 90 & 99.66 & 20 & 5780.00 & 31.06 \\
\hline
\end{tabular}

TABLE 4: Colour fastness properties.

\begin{tabular}{|c|c|c|c|c|c|c|c|}
\hline \multirow{2}{*}{ Sample code } & \multicolumn{2}{|c|}{ Light fastness } & \multicolumn{3}{|c|}{ Wash fastness } & \multicolumn{2}{|c|}{ Rub fastness } \\
\hline & Day light & Artificial light & Effect on shade & Staining on cotton & Staining on wool & Dry & Wet \\
\hline UT & 5 & 5 & 4 & 4 & 4 & 4 & $\overline{4}$ \\
\hline $1 \mathrm{mPT}$ & 5 & 5 & 4 & $4-5$ & 4 & $4-5$ & $4-5$ \\
\hline $2.5 \mathrm{mPT}$ & 5 & 5 & $4-5$ & $4-5$ & $4-5$ & $4-5$ & $4-5$ \\
\hline $5 \mathrm{mPT}$ & 5 & 5 & $4-5$ & $4-5$ & $4-5$ & 5 & $4-5$ \\
\hline $10 \mathrm{mPT}$ & 5 & 5 & $4-5$ & $4-5$ & $4-5$ & 5 & $4-5$ \\
\hline $15 \mathrm{mPT}$ & 5 & 5 & $4-5$ & $4-5$ & $4-5$ & 5 & $4-5$ \\
\hline
\end{tabular}

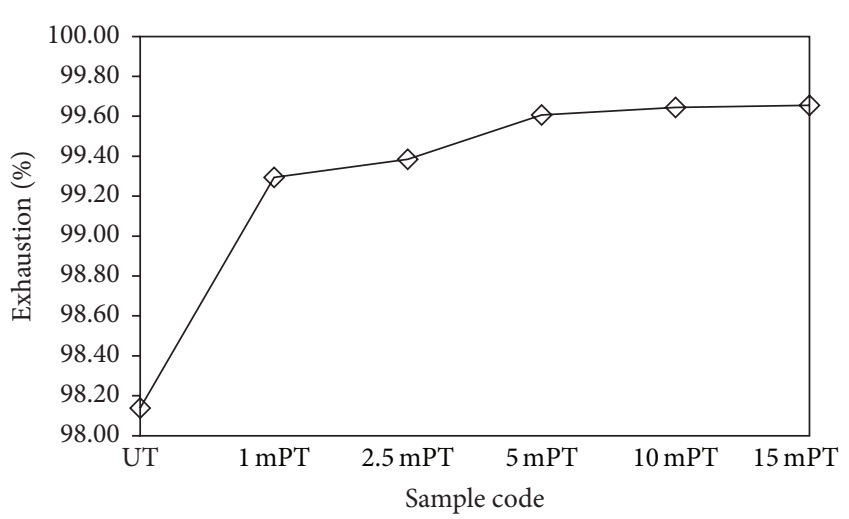

FIgURE 5: Dye exhaustion after 180 min of dyeing on wool fabrics.

of exhaustion was found to reduce for the plasma treated samples (Table 3). The dyeing time was reduced to $90 \mathrm{~min}$ for $5 \mathrm{~min}$ plasma treated sample; however, plasma treatment carried for longer than $5 \mathrm{~min}$ did not reduce time for maximum exhaustion. As compared to the untreated fabric, final exhaustion after 180 min dyeing (Figure 5) was increased by around $1.5 \%$ for 15 min plasma treated fabric.

The substantivity $(K)$ values (Table 3 ) of different dyeing systems were found to increase significantly after the DBD plasma treatment. Therefore, DBD plasma treatment on wool fabric is an effective method to promote dye exhaustion. The $K$ value was found to increase by almost five times for $5 \mathrm{~min}$ plasma treated fabric sample. However, there is no further improvement in substantivity value for samples plasma treated for longer than $5 \mathrm{~min}$. Colour strength $(K / S)$ of dyed wool fabric was found to increase with increase in plasma treatment time; this is due to better exhaustion of dyes after plasma treatment.
Colour fastness to daylight and artificial light (Table 4) was found to be 5 and remained the same for untreated and plasma treated fabric samples. Colour fastness to washing with respect to staining on cotton, wool, and change in shade had improved after the plasma treatment. This is due to the better exhaustion and bonding of dyes to the fabric samples after plasma treatment. Colour fastnesses to dry and wet rubbing were also found to improve after plasma treatment.

The reduction in COD load of the effluent (Table 5) is caused by a higher dye uptake of the plasma treated fabric compared to that of the untreated reference. The BOD for the spent dye bath liquor of plasma treated fabric was found to be higher as compared to untreated sample. There is a possibility that small remnants of wool particles as a result of surface etching may have come into the dye bath, which are biodegradable and can consume more oxygen. The decrease in COD/BOD ratio can be due to decrease in dye concentration in spent dye bath liquor of plasma treated samples as a result of better dye exhaustion. As a consequence of the improved dye bath exhaustion, the final shade of the plasma treated fabric appears darker than that of the correspondingly dyed untreated material, clearly indicating that a plasma treated fabric may require less amount of dyestuff for a given shade. Since dye exhaustion strongly depends on the initial dye concentration, a reduction in the amount of dye used will potentially further contribute to a diminished effluent load.

\section{Conclusions}

(1) Surface topographic analysis of plasma treated wool fibre shows increase in roughness and formation of pores on the surface. Plasma treatment is found to reduce the scale heights of wool fibre and reduction 
TABLE 5: Effluent load in the exhausted dye bath liquor.

\begin{tabular}{lccc}
\hline Sample code & $\begin{array}{c}\text { COD } \\
\mathrm{mg} / \mathrm{L}\end{array}$ & $\begin{array}{c}\text { BOD } \\
\mathrm{mg} / \mathrm{L}\end{array}$ & COD/BOD \\
\hline $\mathrm{UT}$ & 2972 & 800 & 3.72 \\
$1 \mathrm{mPT}$ & 2642 & 1100 & 2.40 \\
$2.5 \mathrm{mPT}$ & 2584 & 1200 & 2.15 \\
$5 \mathrm{mPT}$ & 2424 & 1100 & 2.20 \\
$10 \mathrm{mPT}$ & 2344 & 1200 & 1.95 \\
$15 \mathrm{mPT}$ & 2324 & 1200 & 1.94 \\
\hline
\end{tabular}

in scale height increases with increase in treatment time. Adhesion force is also found to increase with increase in plasma treatment time. It had increased from $1 \mathrm{nN}$ for untreated wool fibre to $6 \mathrm{nN}$ for $15 \mathrm{~min}$ treated fibre clearly indicating six times increase in surface energy or hydrophilicity.

(2) ATR analysis has shown that content of 18-MEA reduces drastically while cysteic acid is introduced on the surface as a result of oxidation of $-\mathrm{S}-\mathrm{S}$ bonds during plasma treatment. Alkali solubility also increases with increase in plasma treatment time.

(3) As a result of these physicochemical changes, wetting time for 15 min plasma treated fabric was found to reduce to 1 second as against nonwettable untreated fabric. The time required to achieve $98 \%$ dye exhaustion (dyeing time) was $120 \mathrm{~min}$ for untreated wool fabric while for 5 min plasma treated fabric, it reduced to $90 \mathrm{~min}$. Plasma treatment carried out for more than $5 \mathrm{~min}$ did not reduce the time for maximum exhaustion. Plasma treatment improves the substantivity, colour strength, and fastness properties of the reactive dye.

(4) Chemical oxygen demand (COD) of spent dye bath liquor had reduced with increase in plasma treatment time but biological oxygen demand (BOD) had increased after plasma treatment while the ratio of $\mathrm{COD} / \mathrm{BOD}$ reduced significantly for the plasma treated wool fabric.

\section{Conflict of Interests}

The authors declare that there is no conflict of interests regarding the publication of this paper.

\section{Acknowledgments}

The authors would like to thank The Ministry of Textiles, Government of India, for funding this research work as a part of R\&D project and would also like to thank Governing Council, WRA for guidance and support.

\section{References}

[1] H. Thomas, "Plasma modification of wool," in Plasma Technologies for Textiles, R. Shishoo, Ed., pp. 228-246, Woodhead Publishing, Cambridge, UK, 2007.
[2] D. M. Lewis, "The coloration of wool," in Advances in Wool Technology, N. A. G. Johnson and I. M. Russell, Eds., pp. 183216, Woodhead Publishing, Cambridge, UK, 2009.

[3] H. Hocker, "Fibre morphology," in Wool: Science and Technology, W. S. Simpson and G. H. Crawshaw, Eds., pp. 60-79, Woodhead Publishing, Cambridge, UK, 2002.

[4] R. Chvalinova and J. Wiener, "Sorption properties of wool fibres after plasma treatment," Chemické Listy, vol. 102, pp. 1473-1477, 2008.

[5] M. Mori and N. Inagaki, "Relationship between anti-felting properties and physicochemical properties of wool treated with low-temperature plasma," Research Journal of Textile and Apparel, vol. 10, no. 1, p. 33, 2006.

[6] A. Demir, H. Karahan, E. Ozdogan, T. Oktem, and N. Seventekin, "The synergetic effects of alternative methods in wool finishing," Fibres \& Text in Eastern Europe, vol. 16, no. 2(67), pp. 89-94, 2008.

[7] J. Udakhe, S. Tyagi, N. Shrivastava, S. Honade, and A. Bhute, "Effect of yarn hairiness, DBD plasma and enzyme treatment on itching propensity of woollen knitwear," Colourage, vol. 61, no. 5, pp. 46-51, 2012.

[8] M. Radetic, P. Jovancic, D. Jocic, T. Topalovic, N. Puac, and Z. L. J. Petrovic, "The influence of low-temperature plasma and enzymatic treatment on hemp fabric dyeability," Fibres \& Text in Eastern Europe, vol. 15, no. 4(63), pp. 93-96, 2007.

[9] C. W. Kan, "Dyeing behavior of low temperature plasma treated wool," Fibres and Polymers, vol. 7, no. 3, pp. 262-269, 2006.

[10] C. W. Kan, "Effect of low temperature plasma on different wool dyeing systems," Autex Research Journal, vol. 8, no. 4, pp. 255263, 2007.

[11] T. Wakida, M. Lee, Y. Sato, S. Ogasawara, Y. Ge, and S. Niu, "Dyeing properties of oxygen low-temperature plasma-treated wool and nylon 6 fibres with acid and basic dyes," Journal of the Society of Dyers and Colourists, vol. 112, no. 9, pp. 233-236, 1996.

[12] S. Ratnapandian, L. Wang, S. Fergusson, and M. Naebe, "Effect of atmospheric plasma treatment on pad-dyeing of natural dyes on wool," Journal of Fiber Bioengineering and Informatics, vol. 4, no. 3, pp. 267-276, 2011.

[13] T. Wakida, S. Cho, S. Choi, S. Tokino, and M. Lee, "Effect of low temperature plasma treatment on color of wool and nylon 6 fabrics dyed with natural dyes," Textile Research Journal, vol. 68, no. 11, pp. 848-853, 1998.

[14] Z. Motaghi, S. Shahidi, and J. Wiener, "Application of low temperature plasma on dye ability of wool with madder," Iranian Physical Journal, vol. 3, pp. 16-23, 2009.

[15] Z. Motaghi and S. Shahidi, "The effect of plasma sputtering on dye ability of the polyester/wool blends fabrics," Journal of Textile Science \& Engineering, vol. 2, no. 3, pp. 1-6, 2012.

[16] R. Atav and A. Yurdakul, "Low temperature dyeing of plasma treated luxury fibres. Part I: results for mohair (Angora goat)," Fibres \& Textiles in Eastern Europe, vol. 19, no. 2(85), pp. 84-89, 2011.

[17] J. Udakhe and S. Honade, "Plasma induced physico-chemical changes \& dyeing behavior of wool fabrics," Colourage, vol. 60, no. 1, p. $41,2013$.

[18] J. Udakhe and S. Tyagi, "Effect of plasma density on surface \& mechanical properties of wool fibres," Man-Made Text India, vol. 39, no. 4, p. 137, 2011.

[19] K. H. Kale and A. N. Desai, "Atmospheric pressure plasma treatment of textiles using non-polymerising gases," Indian Journal of Fibre \& Textile Research, vol. 36, pp. 289-299, 2011. 
[20] J. Coates, "Interpretation of infrared spectra, a practical approach," in Encyclopedia of Analytical Chemistry, R. A. Meyers, Ed., pp. 10815-10837, John Wiley \& Sons, Chichester, UK, 2000.

[21] M. Mirjalili, S. S. Nasirian, and L. Karimi, "Effects of corona discharge treatment on some properties of wool fabrics," African Journal of Biotechnology, vol. 10, no. 83, pp. 19436-19443, 2011.

[22] C.-W. Kan, K. Chan, and Y. C.-W. Marcus, "Surface characterisation of low-temperature plasma treated wool fibre," Autex Research Journal, vol. 3, no. 4, pp. 194-205, 2003. 

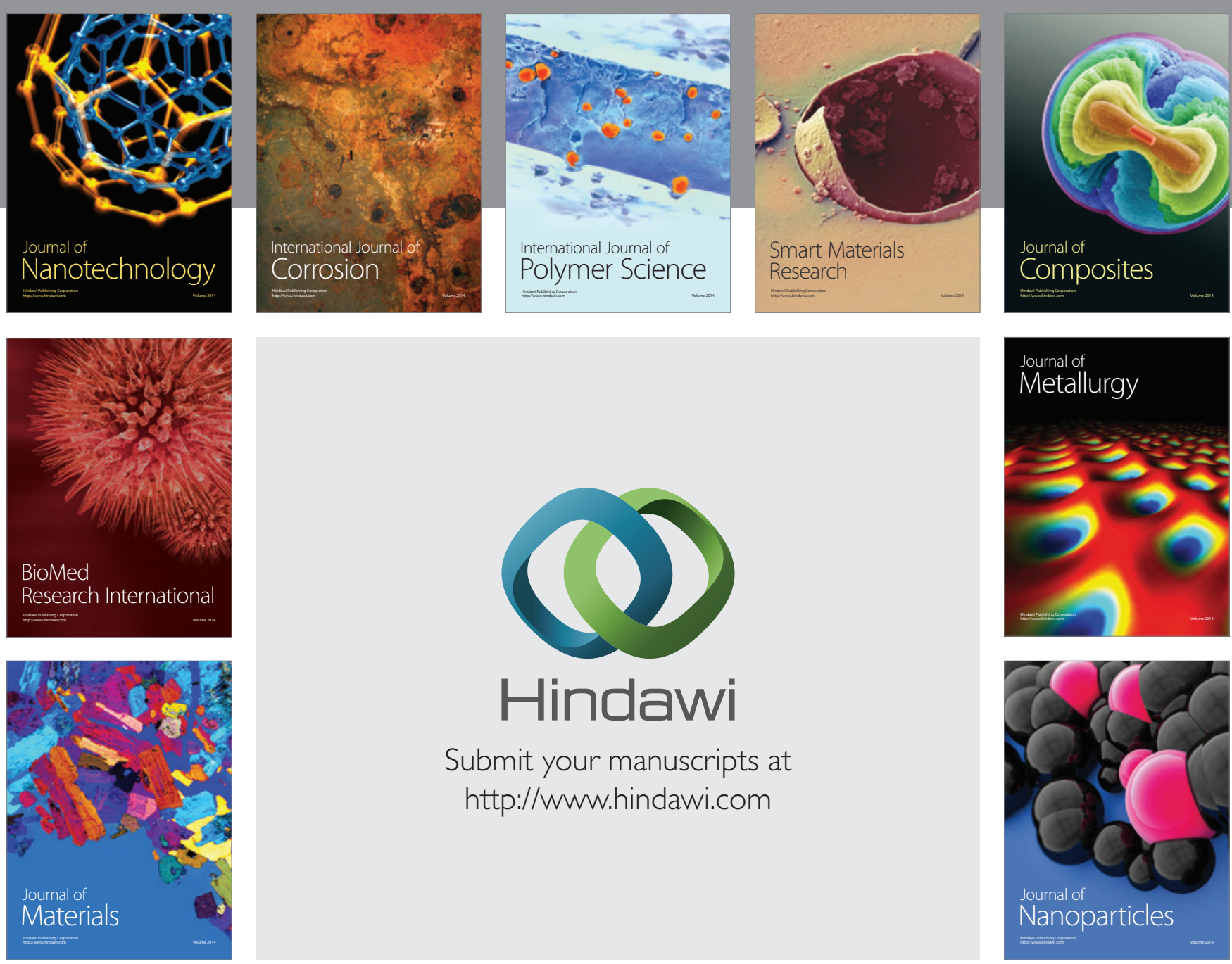

Submit your manuscripts at http://www.hindawi.com
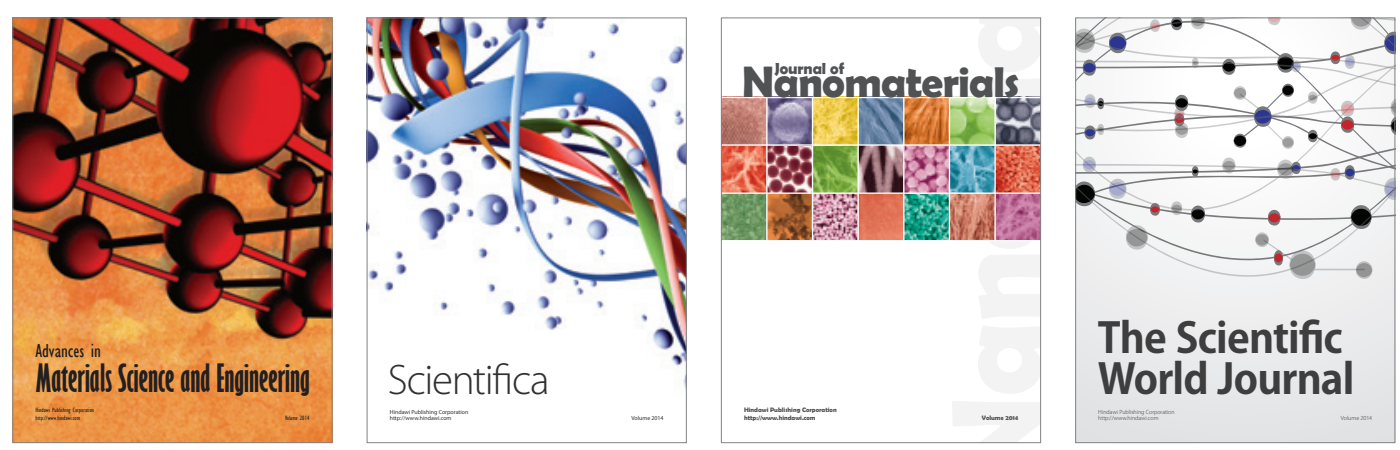

\section{The Scientific World Journal}
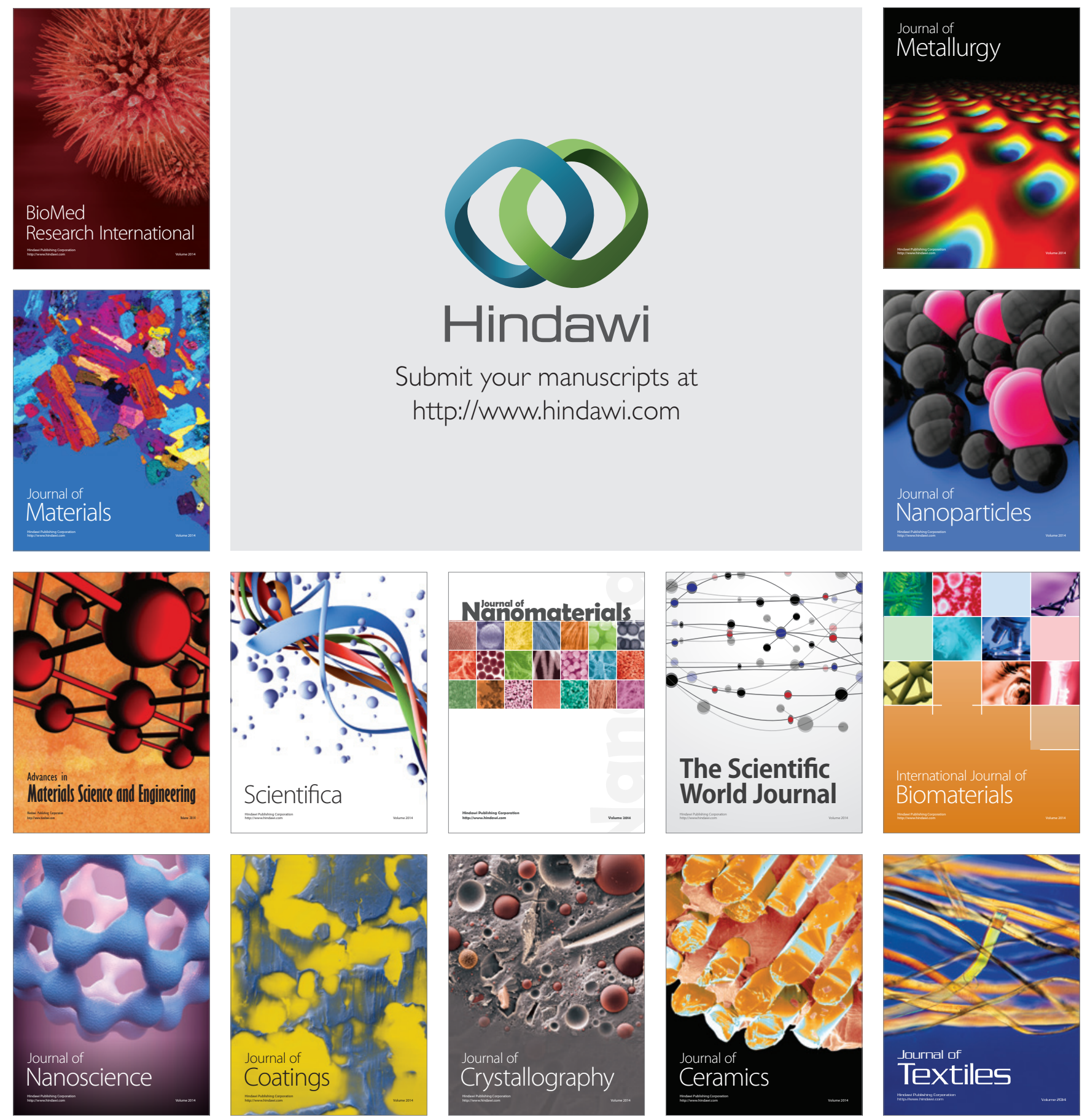